\title{
Familial hyperprolactinemia
}

INSERM

\section{Source}

INSERM. (1999). Orphanet: an online rare disease and orphan drug data base. Familial hyperprolactinemia. ORPHA:397685

Familial hyperprolactinemia is a rare, genetic endocrine disorder characterized by persistently high prolactin serum levels (not associated with gestation, puerperium, drug intake or pituitary tumor) in multiple members of a family. Clinically it manifests with signs usually observed in hyperprolactinemia, which are: secondary medroxyprogesterone acetate (MPA)-negative amenorrhea and galactorrhea in female patients, and hypogonadism and decreased testosterone level-driven sexual dysfunction in male patients. Oligomenorrhea and primary infertility have also been reported in some female patients. 